\title{
Breeding biology of the endangered Yellow Cardinal Gubernatrix cristata in Brazil
}

\author{
Christian Beier ${ }^{1,2} \&$ Carla Suertegaray Fontana ${ }^{1}$ \\ ${ }^{1}$ Laboratório de Ornitologia, Programa de Pós-graduaçáo em Zoologia, Museu de Ciências e Tecnologia, Pontifícia Universidade Católica do Rio \\ Grande do Sul, Porto Alegre, RS, Brazil. \\ 2 Corresponding author: beier.ornito@gmail.com
}

Received on 25 October 2018. Accepted on 27 March 2019.

\begin{abstract}
The Yellow Cardinal, Gubernatrix cristata, has a small geographic range in Brazil, Uruguay, and Argentina. We studied the natural history of the only known Brazilian population of this "Endangered" species ( -50 individuals), which is socially monogamous and may breed cooperatively. During two breeding seasons (October to February 2013-2015), we monitored nests and described the main breeding traits. The breeding season started from the first week of October, with a peak of active nests in midNovember and lasted until mid-February. We found 32 nests, of which 30 were monitored. Female built the open-cup nests in six days $(n=1)$. All nests were built on Prosopis trees, on average at $2.4 \mathrm{~m}$ from the ground. Modal clutch size was three eggs $(n=19)$, and female incubated for 13 days on average $(n=7)$. Hatching rate was $76 \%$ and nestlings fledged after 16 days $(n=6)$. Nestling survival rate was $67 \%$ with mean productivity of 1.6 fledglings/successful nest. Shiny Cowbird, Molothrus bonariensis, parasitized nests of the Yellow Cardinal, with a frequency of $67 \%$ and intensity of 1.9 egg per parasitized nest ( $1-4$ eggs; $n=13$ ). Parasitism in nestlings by botfly larvae (Philornis sp.) occurred in 33\% of nests with nestlings. Nest predation was the main cause of nest losses (73\%) and we recorded a Geoffroy's Cat, Leopardus geoffroyi, preying on a nest with eggs. The probability of success using the Program MARK was $13 \%$. Fledgling survival rate during the first month outside the nest was $62 \%$ ( $8 / 13$ fledglings). We found a longer breeding season, occurrence of second broods, and higher rates but fewer nest losses due to brood parasitism in comparison to the Argentinian population. We highlight the importance of natural history studies for the conservation of different populations of the same species.
\end{abstract}

KEY-WORDS: brood parasitism, Molothrus bonariensis, nest predation, nesting success.

\section{INTRODUCTION}

The Yellow Cardinal, Gubernatrix cristata, is a passerine that was more abundant in the past and now have a very fragmented distribution through northeast Argentina, Uruguay and southern Brazil (Ridgely \& Tudor 2009). Records in Brazil were few and it was even thought that the species was possibly extinct in the country (BirdLife International 2018, Jaramillo 2019). Historical records are concentrated in southern and western Rio Grande do Sul state (Bencke et al. 2003). Nowadays, there is at least one established resident population in the Rio Grande do Sul with less than 50 individuals (Martins-Ferreira et al. 2013, Beier et al. 2017). Bird trapping and habitat loss led to a drastic population decline of the Yellow Cardinal in all its range (Dias 2008, Ridgely \& Tudor 2009, Azpiroz et al. 2012, Martins-Ferreira et al. 2013).

Studies of breeding biology and life-history comparisons between populations enable early identification of threats, even before any evident population decline occur (Martin \& Geupel 1993). Despite the decreasing trend of populations advised for the Yellow Cardinal (BirdLife International 2018), until recently its natural history was poorly known. Previous information about its breeding biology was limited to a few old nesting records (Castellanos 1932, Höy 1969), a nest description (de la Peña 1981), and the breeding status of collected specimens (Belton 1994). Domínguez et al. (2015) published the first study of the breeding biology of a Yellow Cardinal population in Corrientes province, Argentina. Some potential threats to breeding cardinals are nest predation, brood parasitism, botfly parasitism (Domínguez et al. 2015), hybridization (Bertonatti \& López-Guerra 1997), and endogamy (Beier et al. 2017).

Shiny Cowbird, Molothrus bonariensis (hereafter, cowbirds), is a generalist brood parasite and its eggs were found in nests of 270 bird species (Lowther 2018), including Yellow Cardinal (Domínguez et al. 2015). The main impact of cowbirds that parasitize hosts with similar or larger body masses is the egg puncturing, which increases the probability of nest abandonment (Massoni \& Reboreda 2002, Reboreda et al. 2003, Domínguez et al. 2015). Also, botfly larvae, Philornis sp. (Diptera), may infest nestlings of the Yellow Cardinal (Domínguez et al. 2015). Botflies put their eggs on nests of several bird species and their larvae infest the nestlings, feeding 
mainly on blood cells for four to eight days until they drop out to pupate (Dudaniec \& Kleindorfer 2006). Depending on the infestation intensity, i.e. the number of larvae infesting a nestling, it may have negative effects on nestling survival and increase nest abandonment after all nestlings died (Dudaniec \& Kleindorfer 2006, Rabuffetti \& Reboreda 2007).

We studied the breeding biology of the only known population of the Yellow Cardinal in Brazil. The main breeding traits such as breeding season, nest, eggs, clutch size, incubation, nestlings, brood parasitism, and nest survival were described.

\section{METHODS}

\section{Study area}

We conducted this study in the municipality of Barra do Quaraí, state of Rio Grande do Sul, Brazil. Three study areas were in the Espinilho State Park (ESP), and one at São Marcos Ranch (SMR), adjacent to the ESP. The climate is classified as humid subtropical with hot summer (Cfa) in Köppen's climate classification, with 1300 mm accumulated annual rainfall and $19^{\circ} \mathrm{C}$ mean annual temperature (Alvares et al. 2013; maximum $46^{\circ} \mathrm{C}$ was taken by a camera trap in December 2013). The vegetation is characterized by an area of insertion of Espinal Province (Cabrera \& Willink 1973), which consists of grasslands with scattered thorny trees and shrubs, dominated by Prosopis affinis and Vachellia caven (Fabaceae). This is one of the last and the largest reminiscent of this vegetation in Brazil (Marchiori \& Alves 2011). Three areas were grazed by cattle (Fig. 1).

We studied the breeding biology of the Yellow Cardinal from October through February (2013-2015), since nesting activity has not been recorded before October in a previous pilot study. Our dataset is the same used by Beier et al. (2017). We searched for adults at the beginning of each breeding season. Adults found were captured using mist nets and marked with a numbered aluminum ring (standard CEMAVE/ICMBio, the Brazilian Banding Agency) and a unique combination of colored plastic rings. We banded nestlings at 10 days of age or captured soon after fledging.

\section{Nest search}

We searched for nests only in areas with savanna vegetation mainly observing the mating pair, following the female and/or any individual carrying materials for nest building or feeding the nestlings. Each nest found was georeferenced and monitored every two or three days (rarely four or five days), when we recorded the nest status (active and inactive) and contents (number of eggs and/ or nestlings), from the day that nest was found until it became inactive. When it was not possible to infer the exact day that a nest event occurred (laying, start of

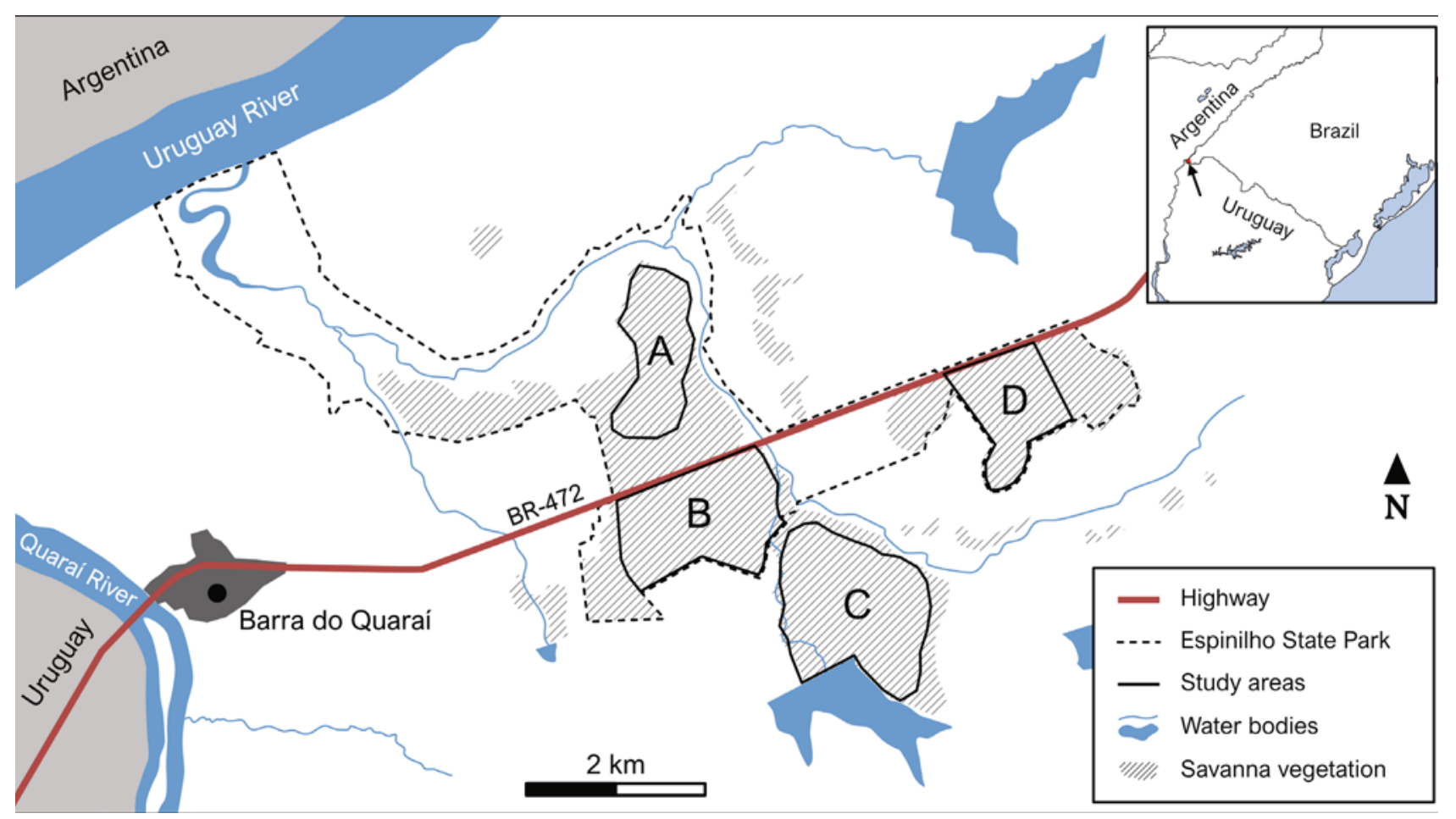

Figure 1. Espinilho State Park with the localization of the four study sites in Barra do Quaraí, Rio Grande do Sul state, at the frontier of Brazil, Argentina, and Uruguay. Study sites B, C, and D were cattle grazed. 
incubation, hatching, fledging or nest loss), we considered that it occurred halfway between nest observations.

\section{Breeding season}

We considered the breeding season length as the period of days between the beginning of the first nest construction and the day the last nest ended, for both breeding seasons together. To estimate the start of the first nest construction in the breeding season, we used the mean duration for each nest period (construction, laying, incubation, and nestling). We estimated nest building initiation date of the first nest based on the mean duration of nesting stages and plumage development of fledglings, for a mating pair found with two fledglings in November 2014. Last day of breeding period was estimated using the approximated date when the last active nest became inactive.

\section{Description of nests and eggs}

We described nest format and support type (as recommended by Simon \& Pacheco 2005), supporting plant species, and materials of which it was composed. The nest construction period was considered from the placing of first materials on nest site until the first egg laying. Nests and eggs were measured only after they were abandoned, or when the egg failed to hatch, to avoid possible negative effects of nest manipulation. Nests were measured using a ruler $(1.0 \mathrm{~mm}$ precision $)$ and nest height was measured using a retractable ruler $(1.0 \mathrm{~cm}$ precision $)$. Egg measurements were taken using a caliper $(0.05 \mathrm{~mm})$ and weighed using a digital scale $(0.01 \mathrm{~g})$.

\section{Clutch size, incubation, and nestlings}

Clutch size was noted at all nests, excluding those with evidence of partial losses during egg laying. The clutch was considered completed after two consecutive visits without an increase in the number of eggs, and only from nests found during building, laying, or up to four days after incubation started (Lopes \& Marini 2005). Incubation period starts after laying of the penultimate to the last egg until hatching, according to our observations and literature (Domínguez et al. 2015). Hatching rate was calculated as the ratio between the number of hatchlings and the number of eggs at hatching (Di Giacomo et al. 2011). Nestling stage starts at hatching and ends when the first nestling leaves the nest, and we used only nests found with eggs and became successful to estimate its duration. Nest productivity was the number of fledglings per successful nest and per female. Nestling survival was calculated as the ratio between the number of fledglings and hatchlings, considering only nests found during construction, egg laying or incubation (Di Giacomo et al. 2011). We calculated fledgling survival as the ratio between the number of young that survived 30 days after fledging (young cardinals disperse after $>10$ months; Beier et al. 2017) and the total number of fledglings. We assumed that fledgling died or was predated when it was not seen with its parents after three consecutive visits (six to nine days), which we considered enough time for the chick be able to follow its parents and to be more easily detected.

\section{Renesting}

We calculated the mean time interval and distance between nesting attempts of the same female on each breeding season. Although only seven females were marked, we assumed that nesting attempts in the same territory were from the same female, especially when there was no evidence of divorce or female death (i.e., male alone for several days and performing courtship displays). At least one individual of the mating pair was marked in all nests (13 nests only the male, four nests only the female, and 13 nests both individuals marked).

\section{Parasitism}

Brood parasitism frequency was the proportion of nests with at least one cowbird egg from the total of nests that completed laying. For calculating brood parasitism intensity, we used the mean number of cowbird eggs per parasitized nests, considering only nests without partial clutch losses. Prevalence of botfly parasitism was calculated as the ratio between the number of parasitized nests and the number of nests where nestlings were at least 5 days old.

\section{Nest survival}

We considered the nest as predated when eggs or nestlings too young to fledge vanished, including nests with eggshells. Nests were considered as abandoned if their contents remained with no sign of parental care. Other potential causes of nest losses were nestling death and brood parasite success. We installed camera-traps (Bushnell Trophy Cam HD) at eight nests to identify nest predators, during incubation and nestling periods, 5-10 $\mathrm{m}$ far from the nests, and recorded a total of $12.5 \mathrm{~h}$ of video. A nest was considered successful when at least one nestling of Yellow Cardinal fledged. We calculated the nest survival using three different methods: (a) the apparent success, as the ratio between the number of successful nests and the total number of monitored nests (Marini $e t$ al. 2010); (b) the Mayfield nesting success, estimating the Daily Survival Rates (DSR) and the probability of success $\left(D^{2} R^{t}\right)$ for each nest period (DSR ${ }^{\mathrm{ti}}$ and $\mathrm{DSR}^{\mathrm{t}}$, where, ti 
$=$ number of days between laying and hatching $=14$ days, tn = number of days between hatching and fledging = 17 days; Mayfield 1975), with modifications suggested by Hensler \& Nichols (1981) to calculate the standard deviation (SD) of the DSR for each period; and (c) the Program MARK, running the null model to calculate the DSR and DSR ${ }^{t}(t=$ number of days between laying and fledging = 31 days; White \& Burnham 1999). Only nests with known fate were used to estimate nest survival. Nest survival was not associated with nesting attempt order, so we considered successive nesting attempts of the same female/pair as independent events (six successful nests of 12 among first, two of six among second, and zero of two among third nesting attempts; chi-squared test: $\chi^{2}(2)=$ 1.36, $P=0.51$; Di Giacomo et al. 2011).

\section{Statistical analysis}

To assess differences on mean time interval and distance between successful and unsuccessful nesting attempts we used non-parametric Mann-Whitney $U$-test (or Wilcoxon rank sum test). We also used $Z$-test to assess differences of DSR and DSR between incubation and nestling stages and parasitized and unparasitized nests. We used $\mathrm{R}$ software (R Core Team 2015) to run the statistical tests. Values are presented as mean \pm SD and considered statistically significant when $P<0.05$.

\section{RESULTS}

\section{Nest search and breeding season}

We found 32 nests, 14 in 2013-2014 of nine breeding pairs and 18 in 2014-2015 belonging to 12 pairs. Two nests found during construction were apparently abandoned (never seen with eggs). Of the 30 remaining nests, six were found during nest-building, eight during egg laying, 13 during incubation, and three nests with nestlings. Both individuals of the pair were marked in 13 nests, only the male was marked in 13 nests and in four nests only the female was marked. We estimated that the beginning of nesting season was 03 October and the last nest became inactive on 12 February, totalizing 131 days. The peak of active nests was in late November (Fig. 2).

\section{Description of nests and eggs}

Nest building was performed by females but closely followed by males. The nest is a high cup/fork, with an external layer of twigs (Prosopis spp.) and an inner layer of thinner sticks, grass, and other plants, lined with filamentous plants and horse/cattle hair. The nest was built in six days $(n=1)$, considering the period from the first twigs until laying of the first egg. Mean nest height was $2.43 \pm 0.67 \mathrm{~m}(1.07-4.43 \mathrm{~m}, n=30)$. Nests were built mostly in Prosopis affinis trees (97\%), and one nest was built in $P$. nigra. Eggs were ovoid with a light bluishgreen background color and black spots (sometimes it could have a few streaks) distributed over the entire surface or concentrated at the blunt pole (Figs. 3A \& C). Mean egg mass was $3.84 \pm 0.15 \mathrm{~g}$ and measured $24.7 \pm$ $1.1 \mathrm{~mm}$ in length and $17.7 \pm 0.6 \mathrm{~mm}$ in width (seven eggs at different ages from three nests).

\section{Clutch size, incubation, nestlings and fledglings}

Mean clutch size was $2.95 \pm 0.52$ eggs ( $2-4$ eggs; mode = 3 eggs; $n=19$ ), laying one egg/day. The incubation was initiated on the penultimate egg laid, lasted $12.9 \pm 0.9$ days (12-14 days; $n=7)$ and only the female incubated the eggs. Hatching rate was $0.76 \pm 0.25(n=14$ nests $)$ and there was no difference between unparasitized and parasitized nests (unparasitized: $0.80 \pm 0.16, n=$ 6; parasitized: $0.73 \pm 0.31, n=8 ; U=23, P=0.95$ ). Hatchlings (Fig. 3B) were orange skinned, with light grey down feathers on the head and back, red-carmine mouth, yellowish gape, and opened their eyes around seven days old. The nestlings (Fig. 3D) remained in the nest for $16.0 \pm 1.3$ days $(15-18$ days; $n=6)$. Nestling survival rate of successful nests was $0.67 \pm 0.28(n=6)$. Mean productivity was $1.6 \pm 0.7(1-3)$ fledglings per successful nests $(n=8)$ and $2.6 \pm 1.8(1-5)$ fledglings per female $(n$ $=5)$. Fledglings had bare nape and belly, with remaining grey down feathers on the crown; greyish and streaked breast, yellowish margins in wing feathers; flight and tail feathers not fully developed; yellowish gape. Fledglings at the age of 35-40 days from hatching were muddy forms of the adult female (Figs. 3E \& F). The fledgling survival rate was $62 \%$ ( $8 / 13$ fledglings).

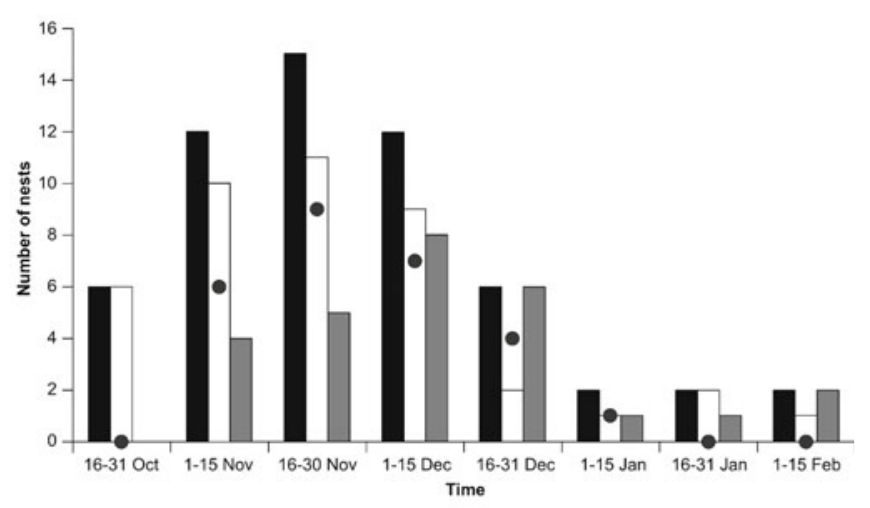

Figure 2. Number of estimated nests of Yellow Cardinal by nesting stage (laying/incubation: white bars; nestling stage: grey bars), total active nests (black bars), and nests parasitized by cowbirds (dots) by two-week intervals during two breeding seasons (2013-2015) in Barra do Quaraí, Rio Grande do Sul state, Brazil. Data from both breeding seasons were combined. 


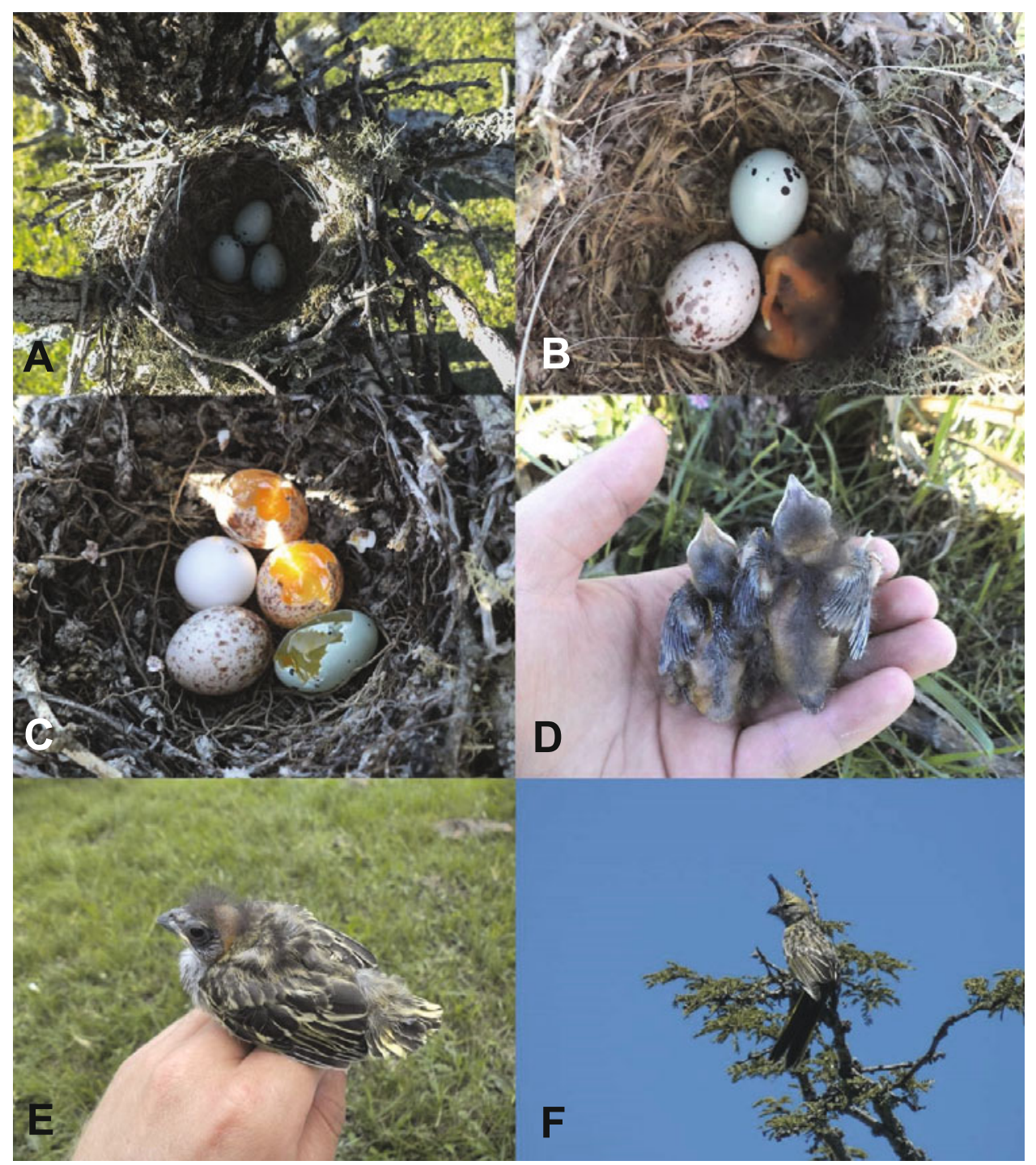

Figure 3. Nest and eggs of Yellow Cardinal in the municipality of Barra do Quaraí, Rio Grande do Sul state, Brazil (A). Nestling in the day of hatching with host egg (top) and brood parasite egg (left of nestling) (B). Destroyed clutch with one egg of Yellow Cardinal and four eggs of Shiny Cowbird, including the white egg (C). Yellow Cardinal nestling (right) and Shiny Cowbird nestling (left) from the same successful nest (D). Yellow Cardinal a few hours after fledged (E). Yellow Cardinal of about 25 days after fledged (F). Photo author: Christian Beier.

\section{Renesting}

We observed up to three nesting attempts performed by the same female (two females). From all nesting attempts, $40 \%$ was renesting, $35.7 \%$ (5 of 14) in 2013-2014 and $43.8 \%$ (7 of 16) in 2014-2015 breeding seasons, eight pairs did one renesting attempt and two pairs did two renesting attempts. We observed renesting after a successful attempt $(n=2)$ in two breeding pairs with helpers. Other two renesting occurred after successful attempts, but the fledglings of the previous nests did not survive the first month after fledging, then we did not consider them as second broods. Mean interval between renesting attempts was $15.6 \pm 10.1$ days ( $6-36$ days, $n=11)$, and the interval was significantly longer after successful $(n=4)$ than after unsuccessful $(n=7)$ attempts $(25.2 \pm 10.3$ days vs. 10.1 \pm 4.3 days; $U=1.5, P=0.02)$. Mean distance between renesting attempts was $220.75 \pm 86.36 \mathrm{~m}$ (99-330 $\mathrm{m}, n$ $=12$ ), and there was no difference between successful $(n$ $=4)$ and unsuccessful $(n=8)$ attempts $(174.75 \pm 74.58 \mathrm{~m}$ vs. $243.75 \pm 86.74 \mathrm{~m} ; U=7, P=0.15)$.

\section{Brood parasitism}

The frequency of brood parasitism was 67\% (20/30). The intensity of parasitism was $1.9 \pm 1.3$ eggs per parasitized nest ( $1-4$ eggs, $n=13)$. Three cowbird eggs measured $25.1 \pm 0.6 \mathrm{~mm}$ in length, $20.4 \pm 0.1 \mathrm{~mm}$ in width and weighed $5.23 \pm 0.12 \mathrm{~g}$. Parasite eggs were white or creamy, completely covered with brown spots, except for one egg 
that was white with a single brown spot (Figs. 3B \& C). Cowbird eggs were never rejected. We found punctured host eggs in 15\% (3/20) of parasitized nests, and then the owners abandoned the nest. Punctured eggs were often consumed by ants. In four parasitized nests $(20 \%, 4 / 20)$ cardinals were successful (unparasitized successful nests: $40 \%, 4 / 10)$. Even on nests where cowbirds hatched ( $n$ $=8)$, in three $(37.5 \%)$, the cardinals were successful and in only one $(12.5 \%)$ the two cowbirds fledged (without cardinal fledglings). In three cases, the cowbird nestling hatched about three or four days after cardinals, and was seen in only one nest revision, then disappeared. In one nest we found the corpse of the cowbird nestling at the bottom of the nest after the cardinals fledged.

\section{Botfly parasitism}

Prevalence of botfly parasitism was 33\% of nests (6/18). In one nest, nestlings were only cowbirds and they were predated. The earliest nest with botflies was recorded on 07 November and the latest on 18 December. Four botfly-parasitized nests $(80 \%, n=5)$ were successful and one nest was lost with the nestling death, for which we were not able to determine the cause. The intensity of bottly parasitism was in average $12.7 \pm 5.5$ larvae/nestling $(n=3)$. We found one nestling with 19 botfly larvae, it fledged but disappeared soon after.

\section{Nest survival}

Only eight nests $(26.7 \%, n=30)$ were successful, four $(28.6 \%, n=14)$ in $2013-2014$ and four $(25.0 \%, n=16)$ in the 2014-2015 breeding seasons. The main cause of nest loss was predation (73\%), followed by egg puncture (14\%), nestling death (9\%) and nest parasite success (4\%) $(n=22)$. One Geoffroy's Cat (Leopardus geoffroyi) was recorded by the camera trap preying on a nest with eggs. The nest was about $1.8 \mathrm{~m}$ above ground, in a fork of the tree trunk. We did not record any other predation attempt or identified other predators.

The DSR was $0.938 \pm 0.018$ during incubation and $0.948 \pm 0.016$ during the nestling stage. The DSR during incubation was $0.431 \pm 0.105$ ( $n=193$ nest-days, 12 nest losses) and during the nestling stage was $0.425 \pm$ 0.117 ( $n=193$ nest-days, 10 nest losses). The Mayfield Nesting Success was $18.3 \%$ (23.65\% in 2013-2014 and $12.32 \%$ in 2014-2015). There was no difference between 2013-2014 and 2014-2015 breeding seasons in DSR for incubation $(0.956 \pm 0.020$ vs. $0.912 \pm 0.033 ; Z=1.12$, $P=0.26)$ and nestling stages $(0.945 \pm 0.025$ vs. 0.951 $\pm 0.022 ; Z=0.18, P=0.86$ ) or in $\mathrm{DSR}^{\mathrm{t}}$ for incubation $(0.568 \pm 0.146, n=113$ nest-days, 5 nest losses vs. 0.285 $\pm 0.138, n=80$ nest-days, 7 nest losses; $Z=1.41, P=$ $0.16)$ and nestling stages $(0.416 \pm 0.167, n=91$ nest- days, 5 nest losses $v$ s. $0.432 \pm 0.166, n=102$ nest-days, 5 nest losses; $Z=0.07, P=0.95$ ).

Mayfield Nesting Success for the Yellow Cardinal was $24 \%$ for unparasitized and $15 \%$ for parasitized nests. There was no difference between the DSR ${ }^{t}$ of unparasitized and parasitized nests during incubation $(0.492 \pm 0.178$, $n=76$ nest-days, 4 nest losses $v$ s. $0.395 \pm 0.132, n=117$ nest-days, 8 nest losses; $Z=0.44, P=0.66$ ) and nestling stage $(0.485 \pm 0.179, n=91$ nest-days, 4 nest losses vs. $0.391 \pm 0.154, n=106$ nest-days, 6 nest losses; $Z=0.40$, $P=0.69)$. For Philornis parasitism, the $\mathrm{DSR}^{t}$ during the nestling stage was $0.279 \pm 0.129(n=105$ nest-days, 8 nest losses) for unparasitized and $0.691 \pm 0.183(n=88$ nest-days, 2 nest losses) for parasitized nests, and there was no significant difference between them $(Z=1.84, P$ $=0.07$ ). We found a DSR of $0.937 \pm 0.013$ (SE) and a $\mathrm{DSR}^{\mathrm{t}}$ of 0.134 , using Program MARK.

\section{DISCUSSION}

The natural history of the Yellow Cardinal was poorly known until recently when a study was conducted in Argentina (Domínguez et al. 2015), relatively close to our study site (at two sites, about 130 and $180 \mathrm{~km}$ northwest, respectively). Despite the geographic proximity, we found some differences: a longer breeding season, occurrence of second broods, and higher frequency and intensity but fewer nest losses due to brood parasitism. Domínguez et al. (2015) conducted their study prior (2011-2012) to ours (2013-2015), so we cannot determine whether the differences found were related to temporal or spatial factors. Additionally, we have already reported cooperative breeding in the Brazilian population (Beier et al. 2017), which was not reported in other populations (Domínguez et al. 2015, Segura et al. 2019).

We found higher frequency (67\%) and intensity ( $\sim 2$ eggs/parasitized nest) of brood parasitism by cowbirds than in Argentina (33\%, 1 egg/parasitized nest; Domínguez et al. 2015). Despite that, only $18 \%$ of nest losses were due to cowbird parasitism in our study. While in Argentina nest abandonment due to egg puncturing by female cowbirds ( $54 \%$ of parasitized nests) represents a threat of concern (Domínguez et al. 2015), in our study, it seems to have lesser importance $(15 \%$ of parasitized nests). Shiny Cowbird has an incubation period of 11-12 days (Fraga 2011), very similar to the Yellow Cardinal (13 days), and cowbird nestlings disappeared from nests where cardinals hatched first. Cowbirds hatchlings may not get enough food competing with cardinal nestlings three or four days older, or the host parents rejected the parasite, for which we do not have other evidence. Brown-headed Cowbird, Molothrus ater, nestlings are more successful in nests of hosts with similar or intermediate body size 
(Kilner 2003), which is the case for Yellow Cardinal (47 g; Beier et al. 2017) and Shiny Cowbirds (45-51 g; Fraga 2011), but we did not find nests where both, host and parasite, were successful.

Prevalence of botfly parasitism was greater in Brazil (33\%) than in Argentina (22\%), occurred during a longer period ( -40 days $v s .14$ days), and apparent success was higher on infested nests $(80 \%, n=5 v$ s. $50 \%$, $n=4$; Domínguez et al. 2015). Domínguez et al. (2015) found no significant difference in chick survival between parasitized (25\%) and unparasitized nests $(78 \%)$. In our study, some fledglings disappeared a few days after they fledged, which we assumed that they died, based on their developmental stage. Ectoparasites may delay the development of the nestling, and even when they do not affect the nestling success, they could decrease the postfledging survival (Streby et al. 2009).

The breeding season was around 45 days longer in Brazil than in Argentina (Domínguez et al. 2015). A longer breeding season could mean more nesting attempts (Ricklefs \& Bloom 1977) and may be a strategy to compensate high rates of nest predation (Slagsvold 1984, Martin 1996, 2014, Di Giacomo et al. 2011), which in our study accounted for $73 \%$ of nest losses. Unless it is too late in the season, females will always renest after nest predation and the number of nesting attempts will be determined by the number of days lost in the breeding season for each nest lost (Schmidt \& Whelan 1999). We observed more renesting attempts (40\% of all nesting attempts) and longer mean interval between attempts (16 days), but less attempts per pair during a breeding season (up to three attempts) than in Argentina (30\%, 12 days, and up to four attempts per pair; Domínguez et al. 2015).

The Yellow Cardinal have biparental care, and some nests $(n=7)$ were also attended by helpers, which contributed to brood provisioning and territorial defense (Beier etal.2017). Cooperative breeding in this population may be a response to high rates of nest predation and brood parasitism, and/or habitat saturation (e.g., Manica \& Marini 2012, Beier et al. 2017). Only mating pairs with nest helpers had second broods, probably due to the extra food and vigilance provided by them. Cooperative breeding may also allow reducing female investment on egg yolk (Russell et al. 2007, Paquet et al. 2013), for which we do not have information for the Yellow Cardinal.

In a pilot study in 2012, we found two nests $(n=$ 8) on cactus Cereus hildmannianus (C.B., M.S. Pereira \& M.S. Borba pers. obs.), but all nests of the present study were found on Prosopis trees. Domínguez et al. (2015) also found more nests on Prosopis affinis (76\%), followed by $15 \%$ on Vachellia caven. Although $V$. caven occurs in our study area, we did not find any nest on that tree species. The preference to nest on a supporting plant species may be related to nest concealment (Martin \& Roper 1988,
Martin 1993) or to the most common potential nest site, reducing predation probability (Martin 1993, Liebezeit \& George 2002).

The Yellow Cardinal and other threatened bird species are also associated with short grass, which is maintained mostly by cattle grazing in our study area (Pereira 2015). The removal of cattle may lead to the development of taller grass and shrub encroachment, and consequently, ground feeding birds could be evicted from this area. Conservation schemes must consider vegetation management to prevent potential impacts on populations of ground-foraging birds.

The natural history of many bird species is still poorly known, if not completely unknown, especially in the Neotropics (Stutchbury \& Morton 2001, Xiao et al. 2017). Various of these species are threatened and the knowledge on their natural histories is of the utmost importance to their conservation. Even across distinct populations of a species, there are remarkable differences, such that each of these populations should be considered as a single unit for the conservation of genetic, ecological and cultural variability, as it is for the Yellow Cardinal (Domínguez et al. 2016, 2017). Our study highlights the importance of autecology studies in different populations of a single species, to allow a better understanding of variations in spatial-temporal patterns and processes and their implications for species and ecosystems conservation.

\section{ACKNOWLEDGEMENTS}

We like to thank Secretaria do Meio Ambiente do Rio Grande do Sul (SEMA-RS) and Espinilho State Park staffs for granting the permissions to research on a protected area, and São Marcos Ranch for granting access to a study site. Sistema de Autorização e Informação em Biodiversidade (SISBIO/ICMBio) and Centro Nacional de Pesquisa e Conservação das Aves Silvestres (CEMAVE) for granting the capture and banding permissions. We also thank Condominio Agropecuário Ceolin, Fazenda São João and Granja Santo Ângelo for its huge support. M. Repenning, M.S. Pereira, A. Pereira, M.S. Borba, E. Chiarani and C.B. Andretti for their fieldwork assistance and ideas. We are grateful to A.B. Azpiroz, A.S. Di Giacomo, J.J. Roper, H. Beier, A.L. Boesing, T.W. da Silva, and anonymous reviewers for suggestions and comments. To Janet W. Reid for English revision. We also like to thank F.P. Tirelli for helping on nest predator identification. C.B. and C.S.F. were supported by a studentship and a research fellowship, respectively, from Conselho Nacional de Desenvolvimento Cientifico e Tecnológico (CNPq). Our fieldwork was substantially funded by Fundação Grupo O Boticário de Proteção à Natureza (grant number 0975_20131). 


\section{REFERENCES}

Alvares C.A., Stape J.L., Sentelhas P.C., Gonçalves J.L.M. \& Sparovek G. 2013. Köppen's climate classification map for Brazil. Meteorologische Zeitschrift 22: 711-728.

Azpiroz A.B., Alfaro M. \& Jiménez S. 2012. Lista roja de las aves del Uruguay: una evaluación del estado de conservación de la avifauna nacional con base en los criterios de la Unión Internacional para Conservación de la Naturaleza. Montevideo: Dirección Nacional de Medio Ambiente.

Beier C., Repenning M., Pereira M.S., Pereira A. \& Fontana C.S. 2017. Cooperative breeding and demography of Yellow Cardinal Gubernatrix cristata in Brazil. Revista Brasileira de Ornitologia 25: 12-19.

Belton W. 1994. Aves do Rio Grande do Sul: distribuição e biologia. São Leopoldo: Editora UNISINOS.

Bencke G.A., Fontana C.S., Dias R.A., Maurício G.N. \& Mähler-Jr. J.K.F. 2003. Aves, p. 189-479. In: Fontana C.S., Bencke G.A. \& Reis R.E. (eds.). Livro vermelho da fauna ameaçada de extinção no Rio Grande do Sul. Porto Alegre: EDIPUCRS.

Bertonatti C. \& López-Guerra A. 1997. Hibridación entre Cardenal Amarillo (Gubernatrix cristata) y Diuca Común (Diuca diuca minor) en estado silvestre, en la Argentina. Hornero 14: 235-242.

BirdLife International. 2018. Species factsheet: Gubernatrix cristata. http://datazone.birdlife.org/species/factsheet/yellow-cardinalgubernatrix-cristata (Access on 07 December 2018).

Cabrera A.L. \& Willink A. 1973. Biogeografia de America Latina. Washington: Organização dos Estados Americanos (OEA).

Castellanos A. 1932. Aves del valle de los Reartes (Córdoba). Hornero 5: $1-40$.

de la Peńa M.R. 1981. Notas nidologicas sobre pepiteros, cardenales, etc. (Aves, Emberizidae), primera parte. Historia Natural 2: 1-4.

Di Giacomo A.S., Di Giacomo A.G. \& Reboreda J.C. 2011. Male and female reproductive success in a threatened polygynous species: the Strange-tailed Tyrant, Alectrurus risora. Condor 113: 619-628.

Dias R.A. 2008. Gubernatrix cristata, p. 536-537. In: Machado A.B.M., Drummond G.M. \& Paglia A.P. (eds.). Livro vermelho da fauna brasileira ameaçada de extinção. Brasília: MMA/Fundação Biodiversitas.

Domínguez M., Reboreda J.C. \& Mahler B. 2015. Impact of Shiny Cowbird and botfly parasitism on the reproductive success of the globally endangered Yellow Cardinal Gubernatrix cristata. Bird Conservation International 25: 294-305.

Domínguez M., Reboreda J.C. \& Mahler B. 2016. Effects of fragmentation and hybridization on geographical patterns of song variation in the endangered Yellow Cardinal Gubernatrix cristata. Ibis 158: 738-746.

Domínguez M., Tiedemann R., Reboreda J.C., Segura L., Tittarelli F. \& Mahler B. 2017. Genetic structure reveals management units for the Yellow Cardinal (Gubernatrix cristata), endangered by habitat loss and illegal trapping. Conservation Genetics 18: $1131-1140$.

Dudaniec R.Y. \& Kleindorfer S. 2006. Effects of the parasitic flies of the genus Philornis (Diptera: Muscidae) on birds. Emu 106: $13-20$.

Fraga R. 2011. Shiny Cowbird (Molothrus bonariensis), p. 786. In: del Hoyo J., Elliott A. \& Christie D.A. (eds.). Handbook of the birds of the world: tanagers to New World blackbirds. Barcelona: Lynx Editions.

Hensler G. \& Nichols J.D. 1981. The Mayfield method of estimating nesting success: a model, estimators and simulation results. Wilson Bulletin 93: 42-53.

Höy G. 1969. Addendas a la avifauna salteña. Hornero 11: 53-56.

Jaramillo A. 2019. Yellow Cardinal. In: del Hoyo J., Elliott A., Sargatal J., Christie D.A. \& de Juana E. (eds.). Handbook of the birds of the world alive. Barcelona: Lynx Editions. https://www.hbw.com/ node/62098 (Access on 22 April 2019).
Kilner R.M. 2003. How selfish is a cowbird nestling? Animal Behaviour 66: 569-576.

Liebezeit J.R. \& George T.L. 2002. Nest predators, nest-site selection, and nesting success of the Dusky Flycatcher in a managed Ponderosa Pine Forest. Condor 104: 507-517.

Lopes L.E. \& Marini M.Â. 2005. Biologia reprodutiva de Suiriri affinis e S. islerorum (Aves: Tyrannidae) no Cerrado do Brasil central. Papéis Avulsos de Zoologia 45: 127-141.

Lowther P.E. 2018. Lists of victims and hosts of the parasitic cowbirds (Molothrus). https://www.fieldmuseum.org/sites/default/files/ cowbird-hosts-05sep2018.pdf (Access on 07 December 2018).

Manica L.T. \& Marini M.Â. 2012. Helpers at the nest of Whitebanded Tanager Neothraupis fasciata benefit male breeders but do not increase reproductive success. Journal of Ornithology 153: 149-159.

Marchiori J.N.C. \& Alves F.S. 2011. A Província do Espinhal no Rio Grande do Sul, p. 8-42. In: Deble L.P., Deble A.S.O. \& Leão A.L.S. (eds.). O Bioma Pampa: contribuiçôes científicas. Bagé: EDIURCAMP.

Marini M.Â., Duca C. \& Manica L.T. 2010. Técnicas de pesquisa em biologia reprodutiva de aves, p. 297-312. In: von Matter S., Straube F.C., Accordi I.A., Piacentini V.Q. \& Cândido-Jr. J.F. (eds.). Ornitologia e conservação: ciência aplicada, técnicas de pesquisa e levantamento. Rio de Janeiro: Technical Books.

Martin T.E. 1993. Nest predation and nest sites: new perspectives on old patterns. Bioscience 43: 523-532.

Martin T.E. 1996. Life history evolution in tropical and south temperate birds: what do we really know? Journal of Avian Biology 27: $263-272$.

Martin T.E. 2014. A conceptual framework for clutch-size evolution in songbirds. American Naturalist 183: 313-324.

Martin T.E. \& Geupel G.R. 1993. Nest-monitoring plots: methods for locating nests and monitoring success. Journal of Field Ornithology 64: 507-519.

Martin T.E. \& Roper J.J. 1988. Nest predation and nest-site selection of a western population of the Hermit Thrush. Condor 90: 51-57.

Martins-Ferreira C., Bencke G.A., Fontana C.S., Dias R.A., Repenning M., Damiani R.V., Mauricio G.N., Gianuca A.T., Krügel M.M., Franz I., Rovedder C.E., Rupp A.E., Pereira M.S., VizentinBugoni J., Joenck C.M., Straube F.C., Reinert B.L., Bornschein M.R., Dias D., Vieira B.P. \& Serafini P.P. 2013. Plano de ação nacional para a conservação dos Passeriformes ameaçados dos Campos Sulinos e Espinilho. Brasília: ICMBio.

Massoni V. \& Reboreda J.C. 2002. A neglected cost of brood parasitism: egg punctures by shiny cowbirds during inspection of potential host nests. Condor 104: 407-412.

Mayfield H.F. 1975. Suggestions for calculating nest success. Wilson Bulletin 87: 456-466.

Paquet M., Covas R., Chastel O., Parenteau C. \& Doutrelant C. 2013. Maternal effects in relation to helper presence in the cooperatively breeding Sociable Weaver. PLoS ONE 8: e59336.

Pereira M.S. 2015. Assembleia de aves territorialistas na formação Espinilho: densidade e seleção de habitat reprodutivo. MSc. Dissertation. Porto Alegre: Pontifícia Universidade Católica do Rio Grande do Sul.

R Core Team. 2015. R: a language and environment for statistical computing. https://www.r-project.org (Access on 15 December 2015).

Rabuffetti F.L. \& Reboreda J.C. 2007. Early infestation by bot flies (Philornis seguyi) decreases chick survival and nesting success in Chalkbrowed Mockingbirds (Mimus saturninus). Auk 124: 898-906.

Reboreda J.C., Mermoz M.E., Massoni V., Astié A.A. \& Rabuffetti F.L. 2003. Impacto del parasitismo de cría del Tordo Renegrido (Molothrus bonariensis) sobre el éxito reproductivo de sus hospedadores. Hornero 18: 77-88.

Ricklefs R.E. \& Bloom G. 1977. Components of avian breeding productivity. Auk 94: 86-96. 
Ridgely R.S. \& Tudor G. 2009. Field guide to the songbirds of South America: the passerines. Austin: University of Texas Press.

Russell A.F., Langmore N.E., Cockburn A., Astheimer L.B. \& Kilner R.M. 2007. Reduced egg investment can conceal helper effects in cooperatively breeding birds. Science 317: 941-944.

Schmidt K.A. \& Whelan C.J. 1999. The relative impacts of nest predation and brood parasitism on seasonal fecundity in songbirds. Conservation Biology 13: 46-57.

Segura L.N., Perelló M., Gress N.H. \& Ontiveros R. 2019. The lack of males due to illegal trapping is causing polygyny in the globally endangered Yellow Cardinal Gubernatrix cristata. Revista Brasileira de Ornitologia 27: 40-43.

Simon J.E. \& Pacheco S. 2005. On the standardization of nest descriptions of Neotropical birds. Revista Brasileira de Ornitologia 13: $143-154$.
Slagsvold T. 1984. Clutch size variation of birds in relation to nest predation: on the cost of reproduction. Journal of Animal Ecology 53: $945-953$.

Streby H.M., Peterson S.M. \& Kapfer P.M. 2009. Fledging success is a poor indicator of the effects of bird blow flies on Ovenbird survival. Condor 111: 193-197.

Stutchbury B.J.M. \& Morton E.S. 2001. Behavioral ecology of tropical birds. Cambridge: Academic Press.

White G. \& Burnham K.P. 1999. Program MARK: survival estimation from populations of marked animals. Bird Study 46: S120-S139.

Xiao H., Hu Y., Lang Z., Fang B., Guo W., Zhang Q., Pan X. \& Lu X. 2017. How much do we know about the breeding biology of bird species in the world? Journal of Avian Biology 48: 513-518.

Associate Editor: Lilian T. Manica. 